\title{
Standardization of Protocol for West Indian Cherry (Malpighia glabra L.) Squash
}

\author{
R. Navya Rani $^{1 *}$, Laxman Kukanoor ${ }^{1}$, Manjula Karadiguddi ${ }^{1}$, \\ N. Srinivas ${ }^{2}$, K.H. Nataraja ${ }^{3}$ and Sumangala Koulagi ${ }^{4}$ \\ ${ }^{1}$ Department of PHT, ${ }^{3}$ Department of FSC, ${ }^{4}$ Department of Plant Pathology, \\ KRCCH, Arabhavi, Karnataka, India \\ ${ }^{2}$ Department of FSC, COH, Bidar, Karnataka, India \\ *Corresponding author
}

\section{A B S T R A C T}

Keywords

West Indian cherry juice, Anthocyanin content, Titratable acidity

Article Info

Accepted:

15 August 2019

Available Online:

10 September 2019
A study was conducted during 2018-2019 in the Department of Post Harvest Technology, Kittur Rani Channamma College of Horticulture, Arabhavi (UHS, Bagalkot), Karnataka. The experiment was consisted with nine different treatments viz., fruit juice concentration $(25,27.5$ and $30 \%)$, TSS $\left(40,45\right.$ and $50^{\circ}$ B) and acidity level (1.0\%) are kept constant, each treatment was replicated thrice in completely randomized design. The results of west Indian cherry squash shows that there was a marginal decreasing trend with respect to parameter like TSS (45.00 to $36.10{ }^{\circ}$ Brix), titratable acidity (1.58 to $1.25 \%$ ), ascorbic acid (965.41 to $702.96 \mathrm{mg} / 100 \mathrm{ml})$, anthocyanin $(3.94$ to $2.18 \mathrm{mg} / 100 \mathrm{~g}$ ), total sugars (35.53 to $34.92 \%$ ) and antioxidant property (93.51 to $67.40 \%$ ), whereas increasing in the $\mathrm{pH}$ (3.10 to 3.41) during the three months after storage.

\section{Introduction}

Barbodas cherry or Acerola or West Indian cherry (Malphigia glabra L.) is a promoting tropical and sub-tropical fruit. The presence of highest natural ascorbic acid content in West Indian cherry fruits aroused interest in this plant among horticulturist as well as food supplement industries. On the other hand, West Indian Cherry pulp have attractive colour and the richest source of vitamin $\mathrm{C}$, vitamin $\mathrm{A}$, lycopene and other antioxidants.
Furthermore, they also contain an adequate amount of minerals and electrolytes such as potassium, manganese, copper, iron and zinc (Pareek and vishal,2006).

The fruits may be consumed fresh or its pulp can be used for preparation of juice, jam, jelly, preserve, syrup etc. The juice or pulp may also be used to increase ascorbic acid contents of various other products. Its juice can be used to blend with other fruit juices to give delicious mixed fruit cocktails and to improve their nutritive value. This crop has not gained 
popularity because of lack of awareness of its cultivation, nutritional value and standard methods to make the processed products (Singh et al., 1999). Fruit juice and squash consumption has been increasing, due to public perception of fruit juices as a healthy natural source of nutrient. As West Indian cherry is highly perishable in nature and has a very limited shelf life of just one - two days and it not so commercially cultivated, hence it must be utilized for processing. If these fruits are processed into commercial value - added products, they form an important nutritional product for all the age group people (Jakhar et al., 2012). The developing of processing technology will help in better utilization of West Indian cherry fruits through value added products preparation like juice, squash, jam, puree, etc. Hence, the present investigation was undertaken to standardize the protocol for west Indian cherry (Malphigia glabra) squash, with different concentration of juice and TSS, also to study their storage behavior.

\section{Materials and Methods}

An experiment was carried out in the laboratory of the department of Post-Harvest Technology, Kittur Rani Channamma College of Horticulture (University of Horticultural sciences, Bagalkot), Arabhavi, Gokak taluk and Belagavi district of Karnataka state during 2018-19. The experiment was laid out in completely randomized design with 9 treatments and 3 replications, in which the treatment varies with fruit juice concentration $(25,27.5$ and $30 \%)$ and TSS $\left(40,45\right.$ and $50^{\circ}$ B).Ripe fruits are harvested from the college orchard, fruits of uniform shape, size, ripened and free from damage were selected and washed in clean water to remove adhering dirt and crushed with the help of basket press for extraction of juice. The extracted juice was taken to prepare squash. Prepared squash was used for analysis of TSS by using an Erma Hand Refractometer, total sugar content, titratable acidity was determined by the procedure given by Ranganna (1997), pH by using digital $\mathrm{pH}$ meter, ascorbic acid by using 2,6-dichlorophenol indophenols (2,6DCPIP), anthocyanin content was recorded by taking an absorbance (O.D) at $510 \mathrm{~nm}$, total phenols were estimated by Folinciocalteau reagent (FCR) method (Bray and Thrope, 1954) and antioxidant activity of juice was determined by free radical activity of the extract was measured in terms of radical scavenging ability using the stable free radical DPPH.

\section{Results and Discussion}

The mean value of TSS and total sugars of squash showed a downward trend in the value from initial to third month from $45.18^{0}$ Brix to $36.10^{\circ}$ Brix and 35.53 to 34.92 per cent respectively. Here controversial results were obtained for both TSS and total sugars, where it decreased slightly throughout the storage period. This result was like the findings noted by Palaniswamy and Muthukrishnan (1974) in jamun squash who also observed a slight increase in TSS initially and then decrease during storage. Jain et al., (1986) found that there was no appreciable change in TSS value during storage of phalsa, kaphal and litchi squashes. The result obtained in this study about this parameter is in conformity with the findings of Hema (1997) in jamun squash and Joy (2003) in rose apple squash.

Maximum titratable acidity value was recorded in treatment $\mathrm{T}_{8}$ (West Indian cherry juice $27.50 \%+\mathrm{TSS} 50^{\circ} \mathrm{B}$ ) and minimum value was recorded in $\mathrm{T}_{1}$ (West Indian cherry juice $25 \%+\operatorname{TSS} 40^{\circ} \mathrm{B}$ ). This might be due to co-polymerization of organic acids with sugars and amino acids (Selvamuthukumaran and Khanum 2013) or due to the chemical interaction between the organic constituents affected by the temperature and action of enzymes (Malav et al., 2014). 
The $\mathrm{pH}$ of the squash is responsible for its flavor and it is inversely proportional to acidity. In the present study the $\mathrm{pH}$ of the squash increase during the storage and their mean value varies from 3.10 at initial to 3.41 at the end of the storage. $\mathrm{pH}$ values affected by various treatments, storage intervals and storage conditions, $\mathrm{pH}$ value showed significant increase in present study. The results of present investigation are in line with the previous finding of Alaka et al., (2003) who observed that the total titratable acidity declined during storage for both fortified and unfortified samples of guava juice stored in different packaging treatments due to the breakdown of ascorbic acid and citric acid.

There was a significant reduction in vitamin $\mathrm{C}$ content of squash during storage from 965.41 $\mathrm{mg}$ per $100 \mathrm{ml}$ to $702.96 \mathrm{mg}$ per $100 \mathrm{ml}$ by the $3^{\text {rd }}$ month after storage. Since, vitamin $\mathrm{C}$ is a strong antioxidant, it oxidizes itself resulting in rapid reduction of vitamin $\mathrm{C}$ during storage. Kalra et al., (1991b) reported that during storage, vitamin $\mathrm{C}$ content decreased by 50 per cent in all market drinks except guava, in which the vitamin $\mathrm{C}$ retention was better.

Table.1 Effect of treatments and storage period on TSS and total sugars of west Indian cherry squash

\begin{tabular}{|c|c|c|c|c|c|c|c|c|}
\hline \multirow[t]{3}{*}{ Treatments } & \multicolumn{4}{|c|}{ TSS ( ${ }^{\circ}$ Brix $)$} & \multicolumn{4}{|c|}{ Total sugars (\%) } \\
\hline & \multicolumn{8}{|c|}{ Months after storage } \\
\hline & $\mathbf{0}$ & $\mathbf{1}$ & 2 & 3 & $\mathbf{0}$ & 1 & 2 & 3 \\
\hline $\mathrm{T}_{1}$-West Indian cherry juice $25 \%+\mathrm{TSS} 40^{\circ} \mathrm{B}$ & 40.33 & 36.07 & 32.10 & 31.23 & 30.40 & 27.95 & 24.89 & 24.33 \\
\hline $\mathrm{T}_{2^{-}}$West Indian cherry juice $27.50 \%+\mathrm{TSS} 40^{\circ} \mathrm{B}$ & 40.67 & 36.13 & 32.20 & 31.13 & 31.17 & 28.30 & 24.92 & 24.30 \\
\hline $\mathrm{T}_{3}$ - West Indian cherry juice $30 \%+$ TSS $40{ }^{\circ} \mathrm{B}$ & 40.33 & 35.20 & 31.17 & 30.47 & 31.07 & 28.05 & 24.31 & 23.79 \\
\hline $\mathrm{T}_{4^{-}}$West Indian cherry juice $25 \%+\mathrm{TSS} 4^{\circ} \mathrm{B}$ & 45.10 & 40.20 & 36.10 & 35.20 & 36.08 & 31.72 & 28.63 & 27.39 \\
\hline $\mathrm{T}_{5^{-}}$West Indian cherry juice $27.50 \%+$ TSS $45^{\circ} \mathrm{B}$ & 45.07 & 40.07 & 36.20 & 36.13 & 36.10 & 31.02 & 28.32 & 27.63 \\
\hline $\mathrm{T}_{6}$ - West Indian cherry juice $30 \%+\operatorname{TSS} 45^{\circ} \mathrm{B}$ & 45.06 & 39.10 & 34.10 & 34.07 & 35.67 & 30.76 & 26.76 & 26.42 \\
\hline 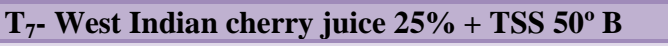 & 50.03 & 46.20 & 45.10 & 42.17 & 39.43 & 35.99 & 34.69 & 33.25 \\
\hline $\mathrm{T}_{8}$-West Indian cherry juice $27.50 \%+$ TSS $50^{\circ} \mathrm{B}$ & 50.03 & 45.10 & 43.10 & 42.40 & 40.23 & 35.36 & 34.49 & 33.51 \\
\hline 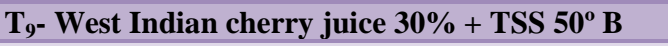 & 50.01 & 45.23 & 43.13 & 42.13 & 39.63 & 35.06 & 34.50 & 33.03 \\
\hline Mean & 45.18 & 40.37 & 37.02 & 36.10 & 35.53 & 31.58 & 29.06 & 28.18 \\
\hline S.Em \pm & 0.27 & 0.10 & 0.09 & 0.11 & 0.31 & 0.49 & 0.46 & 0.40 \\
\hline C.D. @1\% & 1.12 & 0.40 & 0.36 & 0.46 & 1.25 & 1.47 & 1.38 & 1.20 \\
\hline
\end{tabular}

Table.2 Effect of treatments and storage period on titratable acidity and $\mathrm{pH}$ of west Indiancherry squash

\begin{tabular}{|c|c|c|c|c|c|c|c|c|}
\hline \multirow[t]{3}{*}{ Treatments } & \multicolumn{4}{|c|}{ Titratable acidity $(\%)$} & \multicolumn{4}{|c|}{ pH } \\
\hline & \multicolumn{8}{|c|}{ Months after storage } \\
\hline & 0 & 1 & 2 & 3 & $\mathbf{0}$ & 1 & 2 & 3 \\
\hline $\mathrm{T}_{1}-$ West Indian cherry juice $25 \%+\mathrm{TSS} 40^{\circ} \mathrm{B}$ & 1.32 & 1.24 & 1.20 & 1.05 & 3.17 & 3.22 & 3.39 & 3.51 \\
\hline $\mathrm{T}_{2^{-}}$West Indian cherry juice $27.50 \%+\mathrm{TSS} 40^{\circ} \mathrm{B}$ & 1.62 & 1.45 & 1.32 & 1.26 & 3.12 & 3.16 & 3.30 & 3.43 \\
\hline $\mathrm{T}_{3}$ - West Indian cherry juice $30 \%+$ TSS $40^{\circ} \mathrm{B}$ & 1.58 & 1.50 & 1.46 & 1.38 & 3.00 & 3.11 & 3.35 & 3.41 \\
\hline $\mathrm{T}_{4}$ - West Indian cherry juice $25 \%+$ TSS $45^{\circ} \mathrm{B}$ & 1.42 & 1.36 & 1.27 & 1.18 & 3.14 & 3.21 & 3.35 & 3.46 \\
\hline $\mathrm{T}_{5^{-}}$West Indian cherry juice $27.50 \%+\operatorname{TSS} 45^{\circ} \mathrm{B}$ & 1.65 & 1.53 & 1.50 & 1.32 & 3.00 & 3.14 & 3.23 & 3.37 \\
\hline $\mathrm{T}_{6^{-}}$West Indian cherry juice $30 \%+\mathrm{TSS} 45^{\circ} \mathrm{B}$ & 1.48 & 1.23 & 1.18 & 1.10 & 3.11 & 3.19 & 3.33 & 3.45 \\
\hline 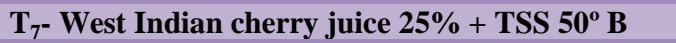 & 1.66 & 1.51 & 1.35 & 1.23 & 3.10 & 3.13 & 3.13 & 3.35 \\
\hline 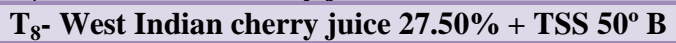 & 1.81 & 1.60 & 1.56 & 1.43 & 3.12 & 3.15 & 3.18 & 3.23 \\
\hline $\mathrm{T}_{9^{-}}$West Indian cherry juice $30 \%+\mathrm{TSS}_{50}^{\circ} \mathrm{B}$ & 1.66 & 1.52 & 1.43 & 1.33 & 3.10 & 3.15 & 3.30 & 3.34 \\
\hline Mean & 1.58 & 1.44 & 1.36 & 1.25 & 3.10 & 3.16 & 3.28 & 3.41 \\
\hline S.Em \pm & 0.07 & 0.06 & 0.07 & 0.09 & 0.04 & 0.02 & 0.05 & 0.05 \\
\hline C.D. @1\% & 0.29 & 0.25 & 0.27 & 0.13 & 0.16 & 0.07 & 0.15 & 0.15 \\
\hline
\end{tabular}


Table.3 Effect of treatments and storage period on ascorbic acid and anthocyanin content of west Indian cherry squash

\begin{tabular}{|c|c|c|c|c|c|c|c|c|}
\hline \multirow[t]{3}{*}{ Treatments } & \multicolumn{4}{|c|}{ Total phenols $(\mathrm{mg} / 100 \mathrm{ml})$} & \multicolumn{4}{|c|}{ Total antioxidant activity $(\%)$} \\
\hline & \multicolumn{8}{|c|}{ Months after storage } \\
\hline & $\mathbf{0}$ & 1 & 2 & 3 & $\mathbf{0}$ & $\mathbf{1}$ & 2 & 3 \\
\hline $\mathrm{T}_{1}$ - West Indian cherry juice $25 \%+\mathrm{TSS} 40^{\circ} \mathrm{B}$ & 2.32 & 2.10 & 1.90 & 1.64 & 97.17 & 83.83 & 74.84 & 68.37 \\
\hline $\mathrm{T}_{2}$ - West Indian cherry juice $27.50 \%+$ TSS $40^{\circ} \mathrm{B}$ & 2.34 & 2.14 & 1.94 & 1.67 & 97.13 & 87.00 & 75.10 & 62.10 \\
\hline $\mathrm{T}_{3^{-}}$West Indian cherry juice $30 \%+$ TSS $40^{\circ} \mathrm{B}$ & 2.74 & 2.51 & 2.31 & 1.91 & 92.30 & 74.73 & 70.67 & 63.27 \\
\hline $\mathrm{T}_{4}-$ West Indian cherry juice $25 \%+\mathrm{TSS} 4^{\circ} \mathrm{B}$ & 2.93 & 2.60 & 2.41 & 2.20 & 96.27 & 88.67 & 75.20 & 72.63 \\
\hline $\mathrm{T}_{5^{-}}$West Indian cherry juice $27.50 \%+\mathrm{TSS} 45^{\circ} \mathrm{B}$ & 2.65 & 2.39 & 2.18 & 1.85 & 97.00 & 85.00 & 76.10 & 60.73 \\
\hline $\mathrm{T}_{6}-$ West Indian cherry juice $30 \%+$ TSS $45^{\circ} \mathrm{B}$ & 2.68 & 2.44 & 2.23 & 1.94 & 92.70 & 88.27 & 74.30 & 63.40 \\
\hline $\mathrm{T}_{7}-$ West Indian cherry juice $25 \%+\mathrm{TSS} 50^{\circ} \mathrm{B}$ & 2.50 & 2.30 & 2.10 & 1.88 & 90.20 & 89.27 & 75.90 & 70.83 \\
\hline $\mathrm{T}_{8^{-}}$West Indian cherry juice $27.50 \%+$ TSS $50^{\circ} \mathrm{B}$ & 3.29 & 3.07 & 2.82 & 2.55 & 91.60 & 86.23 & 75.67 & 74.07 \\
\hline 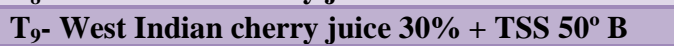 & 2.75 & 2.54 & 2.34 & 2.01 & 87.27 & 85.93 & 75.93 & 71.17 \\
\hline Mean & 2.69 & 2.46 & 2.25 & 1.97 & 93.51 & 85.44 & 74.86 & 67.40 \\
\hline S.Em \pm & 0.15 & 0.14 & 0.14 & 0.14 & 0.19 & 0.18 & 0.79 & 1.12 \\
\hline C.D. @ 1\% & 0.61 & 0.57 & 0.55 & 0.56 & 0.77 & 0.75 & 2.37 & 4.55 \\
\hline
\end{tabular}

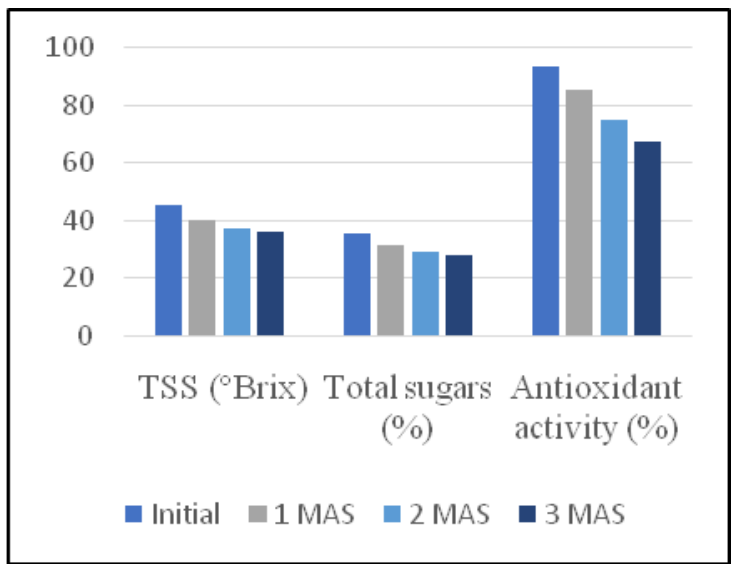

It clearly showed in table, that mean value decreased throughout the storage irrespective of treatments (3.94 to $2.18 \mathrm{mg} / 100 \mathrm{ml}$ ). Loss of anthocyanins in squash might be due to their high susceptibility to auto oxidative degradation (hydrolysis) during storage (Waskar and Khurdiya 1987). Similar results were recorded by Thakur and Thakur (2017) in box myrtle (Myricanagi) squash and Thakur et al., (2018) in wild pomegranate.

The mean value of phenolic content was decreased slightly during the storage intervals from $2.69 \mathrm{mg} / 100 \mathrm{ml}$ at initial to $1.97 \mathrm{mg} / 100$ $\mathrm{ml}$ at three months after storage. The decrease in the total phenol content of squash during storage might be due to their involvement in

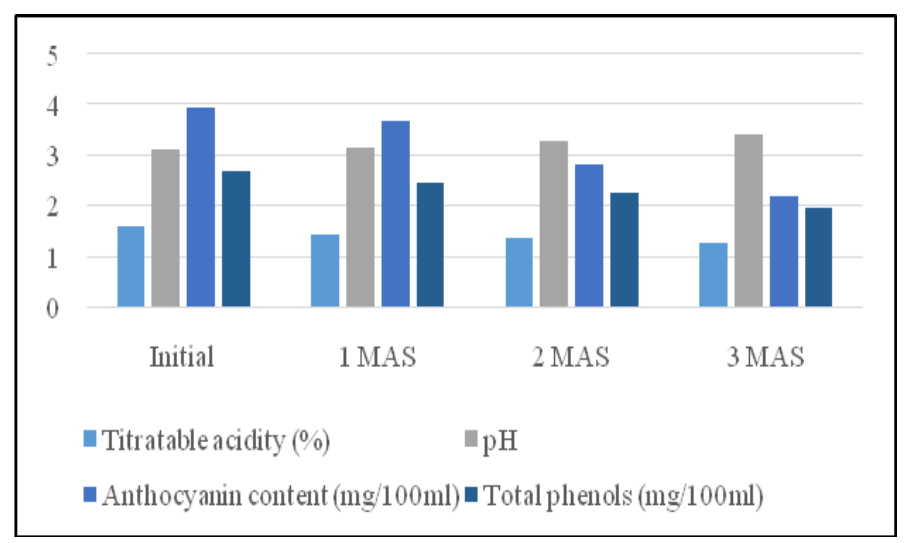

the formation of polymeric compounds by complexing with protein and their subsequent precipitations as also observed earlier (Abers and Wrolstad 1979). Similar results were observed by Kannan and Thirumaran (2001) in jamun squash, Thakur et al., (2018) in wild pomegranate squash.

Among all the treatments mean value of antioxidant property of squash decreased from 93.51-67.40per cent during storage. This might be due to oxidation and release of free radicals or may be reduction in reductones such as ascorbic acid content in squash as compared to fresh fruit (Nagendran et al., 2005) or decrease could occur due to the antioxidant antagonism, which is related to 
the presence of different bioactive compounds and their interactions, resulting in a decrease in antioxidant activity values (FerreiraZielinski et al., 2014). These findings suggest that most of juice samples should be treated as short shelf-life products and that they should be consumed within the first couple of days after opening.

In conclusion, organoleptically acceptable West Indian Cherry squash can be prepared by using West Indian cherry juice at a concentration of 27.50 per cent and maintaining of $50^{\circ} \mathrm{B}$ of TSS $\left(\mathrm{T}_{8}\right)$ and it was followed by $\mathrm{T}_{4}$ (West Indian cherry juice $25 \%$ + TSS $\left.45^{\circ} \mathrm{B}\right)$.

\section{References}

Abers, J. E. and Wrolstad, R. E., 1979, Causative factors of colour determination in strawberry preserves during processing and storage. J. Food Sci. Technol., 44: 75-81.

Anonymous, 1984, Official Methods of Analysis. Ed. Sidney Williams, Association official Analytical Virginia. $14^{\text {th }}$ edition, pp. 424-462.

Akala, O. O., Aina, J. O. and Falade, K. O., 2003, Effect of storage conditions on the chemical attributes of ogbomoso mango juice. Euro. Food Res. Techol.,37(6): 213-217.

Bray, H. G. and Thorpe, W. V., 1954, Standard methods of biochemical analysis. Kalyani Publishers., New Delhi.

Ferreria-Zielinski, C. H. W., Haminiuk, I., Alberti, A., Nogueria, I. M. and Demiate, D. G., 2014, A comparative study of the phenolic compounds and the in vitro antioxidant activity of different Brazilian teas using multivariate statistical techniques. Food Research Inter., pp. 394-400.

Hema, S. R., 1997, Development, diversification and shelf life of jamun (Eugeniajambolana L.) based products. M.Sc. (Home Science) thesis, Kerala Agricultural University, Thiruvananthapuram, p. 223.

Jain, S. P., Tripathi, V. K., Ram, H. B. and Surjeet, S., 1986, Effect of storage conditions on storage life of some important squashes-part II studies on the storage life of phalsa, kaphal and litchi squashes. Indian Food Packer, 40: $36-41$.

Jakhar, M. S., Vaish, P. K. and Pathak, S., 2012, Studies on the standardization and preservation of guava (Psidium guajava L.) and barbados cherry (Malpighia glabra L.) pulp blended ready-to-serve beverage. Inter. J. Proc. and PostHarvest Technol., 3(2): 246-250.

Kalra, S. K., Tandon, D. K. and Singh, B. P., 1991b, Evaluation of mango-papaya blended beverage. Indian Food Packer, 44(1): 33-36.

Kaman, S. and Thirumaran, S., 2001, Studies on storage behavior of jamun product. Beverage and Food World, 29(3): 3233.

Malav, M., Gupta, R. and Nagar, T., 2014, Studies on biochemical composition of orange based blended RTS beverages. Bioscience Biotechnol. Res. Commun., 7(1): 78-83.

Nagendran, B., Tan, Y. A., Ravigadevi, S., Kalyana, S. and Samir, S., 2005, Antioxidant properties of palm fruit extracts. Asia Pac. J. Clin. Nutr., 4 (4): 319-324.

Palaniswamy, K. P. and Muthurkrishnan, C. R., 1974, Studies on physicochemical characters of lemon juice and squashes during storage. Indian Food Packer, 28(4): 37-41.

Pareek, O. P. and Vishal N., 2006, West Indian Cherry- Arid and Minor Fruit. In. Text book of Horticulture, Ed. K. L. Chadha et al., MPH, New Delhi. 
Ranganna, S., 1997, Handbook of analysis and quality control for fruits and vegetable products. 2nd edition. Tata McGraw Hill Publishing Company Ltd. New Delhi.

Selvamuthukumaran, M. and Khanum, F., 2013, Development of spiced sea buckthorn [Elaeagnus rhamnoides $(\mathrm{L})$. A. Nelson syn. HippophaerhamnoidesL.] mixed fruit squash. Indian J. Traditional Knowledge, 13(1), 132-141.

Singh, D. B., Atri, B. L., Suryanarayana, M. A. and Sharma, T. V. R. S., 1999, West Indian Cherry- A rich source of Vitamin C. Agro Indica,3(4): 32.
2017,Development of squash from box myrtle (Myricanagi) and its quality evaluation during storage. J. Hill Agril., 8(1): 87-92.

Thakur, N. S., Dhaygude, G. S., Abhimanyu, T., Pradeep, K. and Hamid., 2018, Studies on preparation and preservation of squash from wild pomegranate (PunicagranatumL.) fruits and its quality evaluation during storage. Int. J. Bio-Resource and Stress Management, 9(1): 07-12.

Waskar, D. P. and Khurdiya, D. S., 1987, Processing and storage of phalsa beverage. Indian Food Packer, 41(5): 716.

Thakur, N. S. and Thakur, A.,

\section{How to cite this article:}

Navya Rani, R., Laxman Kukanoor, Manjula Karadiguddi, N. Srinivas, K.H. Nataraja and Sumangala Koulagi. 2019. Standardization of Protocol for West Indian Cherry (Malpighia glabra L.) Squash. Int.J.Curr.Microbiol.App.Sci. 8(09): 1322-1327.

doi: https://doi.org/10.20546/ijcmas.2019.809.151 